\title{
Incidence of pituitary autoantibodies in idiopathic diabetes insipidus
}

\author{
PAWEE GUT, AGATA CZARNYWOJTEK, KATARZYNA ZIEMNICKA, \\ JOANNA WALIGÓRSKA-STACHURA, NADIA SAWICKA-GUTAJ, MACIEJ BACZYK, \\ JAKUB FISCHBACH, KOSMA WOLIŃSKI, ELŻBIETA WROTKOWSKA, MAREK RUCHAEA
}

Department of Endocrinology, Metabolism and Internal Medicine, Poznań University of Medical Sciences, Poznań, Poland

\begin{abstract}
Diabetes insipidus is a disorder resulting from insufficient action of vasopressin (ADH) characterized by excretion of highly diluted urine in large amounts. Idiopathic diabetes insipidus is associated with the presence of both autoantibodies against ADH-secreting neurons and pituitary autoantibodies. The aim of the present study was to evaluate the occurrence of autoantibodies against the pituitary microsomal fraction. The study included 33 sera of diabetes insipidus patients and 10 control sera obtained from 10 healthy persons. In all patients the secretion of pituitary hormones and thyroid autoantibodies was assessed. Human pituitaries were obtained during autopsy and homogenized in $0.01 \mathrm{~mol} / \mathrm{l} \mathrm{pH} 7.4$ phosphate buffer. In addition, for the autoantibody evaluation, the electrophoretic method of separation in polyacrylamide gel and western blot were employed. Among the 33 subjects, in 23 patients the presence of autoantibodies against the pituitary was shown. Sera of 15 patients reacted with the pituitary microsomal fraction protein of $55 \mathrm{kDa}$. In other cases, 10 sera reacted with the pituitary antigen of $67 \mathrm{kDa}$. In addition, 5 sera reacted with the $60 \mathrm{kDa}$ antigen, 5 sera with $52 \mathrm{kDa}$ protein, 3 sera with $105 \mathrm{kDa}$ protein, 3 sera with the $97 \mathrm{kDa}$ antigen and 2 sera with pituitary antigen of $92 \mathrm{kDa}$ weight. In our study, based on the immunoblotting method, we observed that pituitary autoantibodies against 55, 60 and $67 \mathrm{kDa}$ antigens occurred frequently.
\end{abstract}

Key words: diabetes insipidus, pituitary autoantibodies, immunoblotting.

(Centr Eur J Immunol 2018; 43 (4): 428-433)

\section{Introduction}

Diabetes insipidus is a disorder resulting from insufficient action of vasopressin (ADH) characterized by excretion of highly diluted urine in large amounts. The disorder must be differentiated from other states of excessive urine, such as primary polydipsia and osmotic diuresis. In fact, central (neurogenic) diabetes insipidus is caused by failure of the posterior part of the pituitary, whereas renal diabetes insipidus occurs when the kidneys do not respond to $\mathrm{ADH}$. The causes of central diabetes insipidus include surgery of pituitary tumors, tumors of the hypothalamus, such as craniopharyngioma, granulomatous diseases or histiocytosis. What is more, familial central diabetes insipidus, which is a recessive inherited disorder, is rare and manifests in infancy. Additionally, the autosomal dominant form occurs in association with diabetes, optic nerve atrophy, and deafness (DIDMOAD - Wolfram syndrome). The idiopathic form of diabetes insipidus is associated with the presence of autoantibodies against ADH-secreting neurons, as well as of pituitary autoantibodies. Furthermore, this form is often accompanied by other autoimmune diseases. Previ- ous studies have shown that pituitary autoantibodies are present in the sera of most pituitary disease patients [1-3], as well as in patients with other autoimmune diseases of the endocrine glands, such as Graves' disease or Addison's disease $[4,5]$. To demonstrate the presence of serum autoantibodies, immunofluorescence involving frozen sections of human pituitary gland [6], or pituitary cell lines, such as rat GH3 or mouse AtT20, were typically used [7, 8]. The presence of pituitary autoantibodies was first identified in 1975 by Bottazzo et al. $[9,10]$ in patients with autoimmune polyendocrine syndrome. They also studied 287 patients with various autoimmune endocrine diseases and in 19 cases antibodies against lactotrophic pituitary cells were identified using immunofluorescence. Subsequent studies based on the immunoblotting method involving antigen isolated from human pituitary gland indicated the presence of antibodies against antigenic proteins of the pituitary in the range of 14 to $98 \mathrm{kDa}$ in sera of patients with various autoimmune endocrine diseases. On the other hand, some sera react with several antigenic proteins varying in weight, and some only with a single protein of a specific gravity [11]. Bando et al. described the presence of IgG4

Correspondence: Paweł Gut, PhD, MD, Department of Endocrinology, Metabolism and Internal Medicine, Poznań University of Medical Sciences, Przybyszewskiego 49, 60-355 Poznań, Poland, e-mail: gutpj@ poczta.onet.pl

Submitted: 24.06.2016; Accepted: 9.09.2018 
antibodies in the hypothalamic-pituitary inflammation area in 19 out of 32 cases [12]. Similar results were presented by Nakasone et al., who described the rapid conversion of hypothalamus inflammation towards the empty sella syndrome [13]. Moreover, Scherbaum et al. presented data concerning the prevalence of antibodies against vasopressin-secreting cells in 11 patients suffering from idiopathic diabetes insipidus [14]. Similar reports were presented by Pivonello et al., confirming the presence of hypothalamic autoantibodies in 53\% of patients with central diabetes insipidus [15]. Additionally, Maghnia et al. demonstrated the co-existence of pituitary autoantibodies (anti-glutamic acid decarboxylase - GAD) and anti-islet (tyrosine phosphatase - IA2) in patients with central diabetes insipidus [16]. De Bellis et al. presented a significant correlation in the coexistence of both pituitary and hypothalamic antibodies [17].

Chilorio et al. pointed out the coexistence of pituitary autoantibodies and anti-nuclear antibodies (anti-ANA) [18]. The aim of the present study was to evaluate the occurrence of autoantibodies against the pituitary microsomal fraction, as well as molecular weight characterization of autoantigens by immunoblotting in patients with the idiopathic form of diabetes insipidus.

\section{Material and methods}

The study included 33 sera of patients diagnosed with idiopathic central diabetes insipidus. The studied group involved 20 women aged 33 to 65 years (average $47.3 \pm 8.4$ ), and 13 men aged 39 to 59 years (average $44.3 \pm 7.1$ ). In all patients the diagnosis had been confirmed on the basis of biochemical tests: plasma and urine osmolality, dehydration test and the vasopressin test. Furthermore, in all patients the pituitary hormone secretion in the circadian rhythm and in stimulation tests was evaluated. As a result, panhypopituitarism was observed in 23 cases, partial hypopituitarism (ACTH deficiency) in 5 cases, and in 5 cases the pituitary function was normal. Additionally, all patients underwent thyroid antibody assays (a-TPO, a-TG, TRAb). Commercial ELISA kits were employed in order to determine thyroid antibodies. Pituitary gland MRI was performed in all cases to exclude an organic cause of the disease. However, the study did not include patients with hypopituitarism and diabetes insipidus following neurosurgery of adenoma and craniopharyngioma. Additionally, the study also excluded patients with Sheehan and empty sella syndrome, as well as subjects following radiotherapy. Physiologically, anterior and posterior parts of the pituitary are distinct in MRI. The anterior part is isointense on both T1 and T2 weighted images. However, the posterior pituitary has an intrinsic high $\mathrm{T} 1$ signal (bright spot) and is hypointense on T2 weighted images. In the studied group symmetric enlargement of the pituitary gland, a thickened pituitary stalk and an intact sellar floor with absence of a posterior pituitary bright spot were found in 27 cases with partial and complete hypopituitarism. In 5 patients presenting normal function of pituitary and diabetes insipidus only the lack of a posterior pituitary bright spot was revealed. The control sera were obtained from 10 healthy persons including 7 women and 3 men aged 21 to 45 years (average $30.6 \pm 7.1$ ). Human pituitaries were taken during autopsy and homogenized in $0.01 \mathrm{~mol} / \mathrm{l} \mathrm{pH} 7.4$ phosphate buffer. After connective tissue removal, homogenate was centrifuged for 20 minutes at $4^{\circ} \mathrm{C}$ at $900 \times \mathrm{g}$ in a refrigerated centrifuge. The precipitate was removed, and subsequently centrifugation at 27000 $\times \mathrm{g}$ for 30 minutes was performed. The supernatant was centrifuged at $105000 \times \mathrm{g}$ for one hour and the resultant precipitate was suspended in phosphate-hydrochloric acid buffer with ultracentrifugation repeated four times. The protein content of the obtained sediment was determined by spectrophotometry. The obtained microsomal fraction of human pituitary glands was then solubilized in $1 \%$ sodium deoxycholate. For the evaluation of the autoantibodies, the electrophoretic method of separation in polyacrylamide gel (SDS-PAGE) and western blot (immunoblotting) were employed. For the purpose of the study, $12.5 \%$ separation gel and a $6 \%$ thickening gel were prepared. The microsomal fraction was denatured in a solution composed of 0.3 mol/1 Tris- $\mathrm{HCl}$, pH 6.8, 6\% SDS, 30\% glycerol, $6 \%$ 2 -mercaptoethanol and $0.1 \%$ bromophenol blue in proportions allowing for obtaining protein concentration of $1 \mathrm{mg} /$ $\mathrm{ml}$. Preparations of pituitary microsomal fraction were subsequently applied in an amount of $40 \mathrm{ml}$ per each gel pocket. A similar procedure was performed with model proteins (Pharmacia). After separation completion by SDS-PAGE, proteins were electrophoretically transferred to a nitrocellulose membrane (Bio-Rad) in the presence of buffer (25 mM Tris, $190 \mathrm{~mm}$ glycine, 20\% methanol) at $\mathrm{pH} 8.3$. Incubation with tested sera was carried out at $+4^{\circ} \mathrm{C}$ in $1: 200$ dilution for 16 hours. Incubation with the second antibody (anti-human IgG labeled with horseradish peroxidase) was carried out at room temperature for 1 hour and chemiluminescence reaction was subsequently performed followed by autoradiography (ECL kit - Amersham).

\section{Results}

Among the 33 studied patients with central diabetes insipidus the presence of autoantibodies against pituitary was revealed in 23 cases. Sera of 15 patients reacted with the pituitary microsomal fraction protein of $55 \mathrm{kDa}$ specific gravity. In other cases, 10 sera reacted with the pituitary antigen of specific gravity of $67 \mathrm{kDa}$. In addition, 5 sera reacted with the $60 \mathrm{kDa}$ antigen, 5 sera with the $52 \mathrm{kDa}$ protein, 3 sera with the $105 \mathrm{kDa}$ protein, 3 sera with the $97 \mathrm{kDa}$ antigen and 2 sera with pituitary antigen of $92 \mathrm{kDa}$ weight. Furthermore, it should be noted that 6 sera reacted with both the microsomal fraction protein of the human pituitary gland of a specific gravity of 67 and $55 \mathrm{kDa}$, 
Table 1. Results of SDS-PAGE and Western blot from diabetes insipidus patients' sera with pituitary autoantigens

\begin{tabular}{|c|c|c|c|c|}
\hline No. & Patient & $\operatorname{Sex}(\mathbf{F} / \mathbf{M})$ & $\begin{array}{c}\text { Age } \\
\text { (years) }\end{array}$ & $\begin{array}{c}\text { Molecular weight of } \\
\text { pituitary antigens }(\mathrm{kDa})\end{array}$ \\
\hline 1 & M.C. & $\mathrm{F}$ & 54 & $20,55,67,97$ \\
\hline 2 & S.U. & $\mathrm{F}$ & 42 & $20,55,60,67,97$ \\
\hline 3 & P.H. & $\mathrm{F}$ & 61 & 55 \\
\hline 4 & Z.K. & $\mathrm{F}$ & 49 & 55 \\
\hline 5 & M.G. & $\mathrm{F}$ & 52 & 55 \\
\hline 6 & W.L. & $\mathrm{F}$ & 63 & $20,55,60,67$ \\
\hline 7 & W.D. & $\mathrm{F}$ & 57 & $20,55,60,67,97,105$ \\
\hline 8 & K.A. & $\mathrm{F}$ & 47 & 36,55 \\
\hline 9 & K.K. & $\mathrm{F}$ & 49 & 36,55 \\
\hline 10 & R.K. & M & 58 & 55 \\
\hline 11 & N.Z. & $\mathrm{F}$ & 59 & 55,105 \\
\hline 12 & R.A. & M & 41 & 67 \\
\hline 13 & N.J. & $\mathrm{F}$ & 66 & 44,67 \\
\hline 14 & S.B. & $\mathrm{F}$ & 58 & $20,36,52,55$ \\
\hline 15 & S.M. & $\mathrm{F}$ & 42 & $52,55,67,92$ \\
\hline 16 & M.P. & $\mathrm{F}$ & 37 & 67 \\
\hline 17 & D.M. & $\mathrm{F}$ & 52 & 52 \\
\hline 18 & S.T. & $\mathrm{F}$ & 41 & $18,52,92,105$ \\
\hline 19 & P.G. & $\mathrm{F}$ & 33 & 67 \\
\hline 20 & S.V. & $\mathrm{F}$ & 56 & $20,55,67$ \\
\hline 21 & K.G. & $\mathrm{F}$ & 37 & 36,55 \\
\hline 22 & L.A. & $\mathrm{F}$ & 62 & 36,52 \\
\hline 23 & O.B. & M & 48 & 36,60 \\
\hline
\end{tabular}

and 4 sera reacted with the proteins of gravity 55, 60 and $67 \mathrm{kDa}$. In the group of patients with diabetes insipidus, 4 sera reacted with a single pituitary antigen of $55 \mathrm{kDa}$ weight and 3 sera reacted only with a single protein of $67 \mathrm{kDa}$ weight. Other sera of this patient group reacted with several pituitary microsomal proteins, up to six with different weights from 18 to $105 \mathrm{kDa}$.

Detailed results of diabetes insipidus patients' sera following immunoblotting using pituitary microsomal proteins are shown in Table 1, as well as in Figures 1 and 2. However, in the control group 1 of 10 tested sera gave a weak reaction with only one pituitary microsomal fraction protein of a specific gravity of $55 \mathrm{kDa}$.

For the determination of antibodies against thyroid peroxidase, thyroglobulin and thyroid stimulating hormone (TSH) receptor, commercial ELISA kits were used. The serum was considered positive for thyroid autoimmunity in the concentration greater than $60 \mathrm{IU} / \mathrm{ml}$ in both a-TPO and a-TG, and greater than $2 \mathrm{IU} / \mathrm{ml}$ in TRAb. In the study of a-TPO antibody prevalence, elevated concentrations of

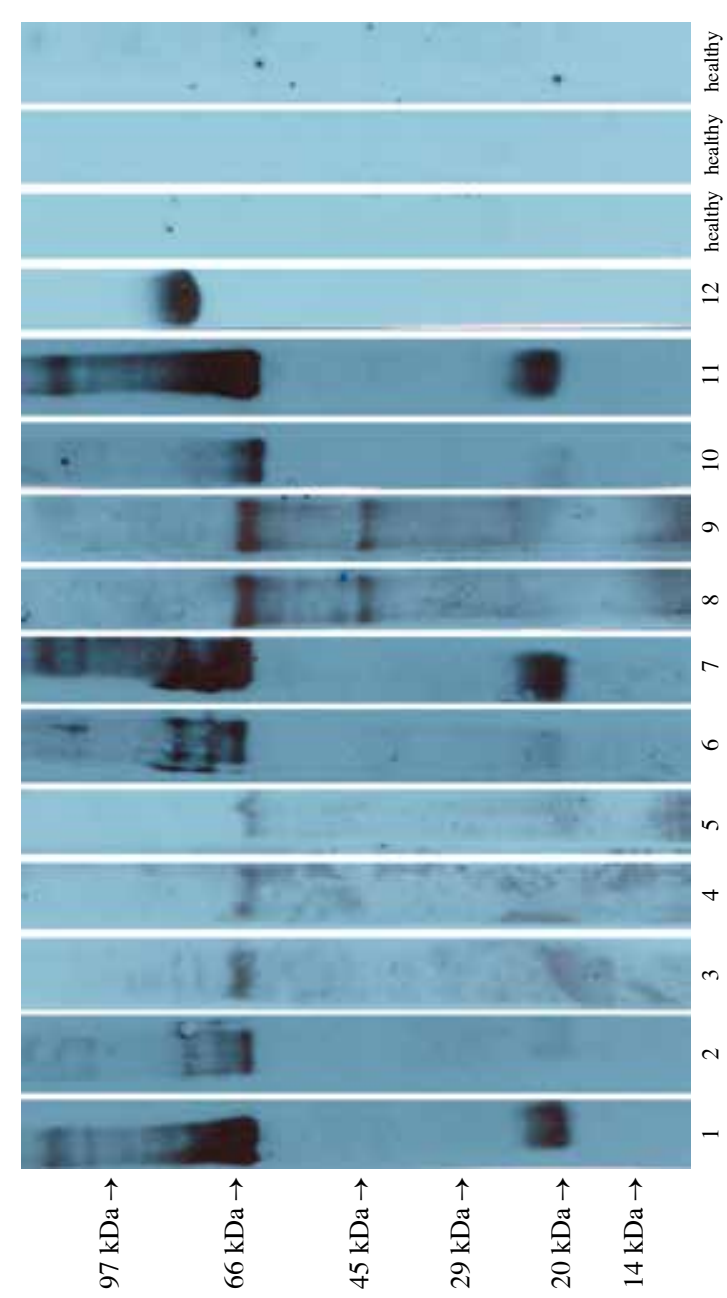

Fig. 1. Immunoblotting of pituitary microsomal proteins with sera from diabetes insipidus patients (1-12) and from control subjects (healthy)

antibodies were found in 20 of 33 tested patients. The antibody concentration ranged from 89 to $987 \mathrm{IU} / \mathrm{ml}$ with an average $406 \mathrm{IU} / \mathrm{ml}$. In the study of a-TG antibody prevalence, a positive reaction was found in 15 of 33 patients, where the antibody concentration ranged from 69 to 342 $\mathrm{IU} / \mathrm{ml}$ with an average $119 \mathrm{IU} / \mathrm{ml}$. In the case of TRAb antibodies only 3 patients presented an elevated concentration, ranging from 2.1 to $3.2 \mathrm{IU} / \mathrm{ml}$, with an average 2.7 IU/ml (Table 2).

\section{Discussion}

The clinical presentation of lymphocytic hypophysitis can vary depending on the part of the pituitary affected, as well as on the size of the lesion. Lymphocytic hypophysitis can be classified as adenohypophysitis (anterior pituitary), lymphocytic infundibular neurohypophysitis (posterior pituitary) or lymphocytic infundibular panhypophysitis 
(affecting both the anterior and posterior pituitary). In the studied group partial or complete hypopituitarism was observed in 28 cases, whereas in 5 cases the pituitary function was normal. In our study based on the immunoblotting method, we frequently observed the presence of autoantibodies directed mainly against the microsomal fraction of human pituitary autoantigens of specific gravities (namely 55,60 and $67 \mathrm{kDa}$ ) in the sera of patients with diabetes insipidus. Furthermore, 10 patients revealed no pituitary antibodies. This may be due to low antibody titers or the need to use more sensitive methods. It is worth mentioning that thyroid antibodies coexist (a-TPO positive in 20 cases, a-TG positive in 15 cases and TRAb positive in 3 cases) in many diabetes insipidus patients. These results may suggest the complexity of autoimmunity, as in patients with diabetes insipidus there is a plurality of autoantibodies against a number of microsomal pituitary antigens. Therefore in order to determine their nature, there is a need for further studies including characterization of their specificity. Furthermore, it is also possible that a more diverse autoimmune process is involved in the study, where antigens may come from different tissues. Such a wide range of pituitary autoantibodies present in autoimmune diseases may relate to the existence of five different types of cells originating from the anterior part of the pituitary gland secreting six different hormones. In fact, Falorni et al. describe the presence of autoantibodies in patients with lymphocytic inflammation of the pituitary gland. Moreover, they observed the presence of antibodies against alpha-enolase, gamma-enolase and anti-PGSF1 and anti-PGSF2 (pituitary gland specific factor) in $45 \%$ of patients [19]. Ziemnicka et al., using the immunoblotting method, described pituitary autoantibodies against antigens of weights of 67, 60, 50 and $36 \mathrm{kDa}$ in congenital hypopituitarism patients [20]. Bensing and Kasperlik-Załuska and Czarnocka [21, 22] described the presence of pituitary antibodies in an isolated ACTH deficiency. In the study antigenic proteins isolated from cytosolic fractions of pituitaries were used, where in $18.5 \%$ of cases the presence of antibodies against $36 \mathrm{kDa}$ antigens and in $21.5 \%$ of the cases the presence of $49 \mathrm{kDa}$ antigen were revealed. Crock et al. [23, 24] studied the prevalence of pituitary antibodies involving immunoblotting in different endocrinopathies, where pituitary autoantigens isolated from cytosolic fractions of pituitaries were used. The above-mentioned studies demonstrated the presence of antibodies against the human pituitary of 40 and $49 \mathrm{kDa}$ weights in $70 \%$ of patients with lymphocytic inflammation of the pituitary gland. Nishiki et al. [25] observed the presence of antibodies against membrane proteins of the pituitaries of 68,49 and $43 \mathrm{kDa}$ weights in patients with lymphocytic inflammation of the pituitary gland as well as in patients with autoimmune thyroid diseases. Lim et al. [26], using immunoenzymatic methods, demonstrated that pituitary antibodies may be present in $36 \%$ of Hashimoto's thyroiditis patients. In fact, similar observa-

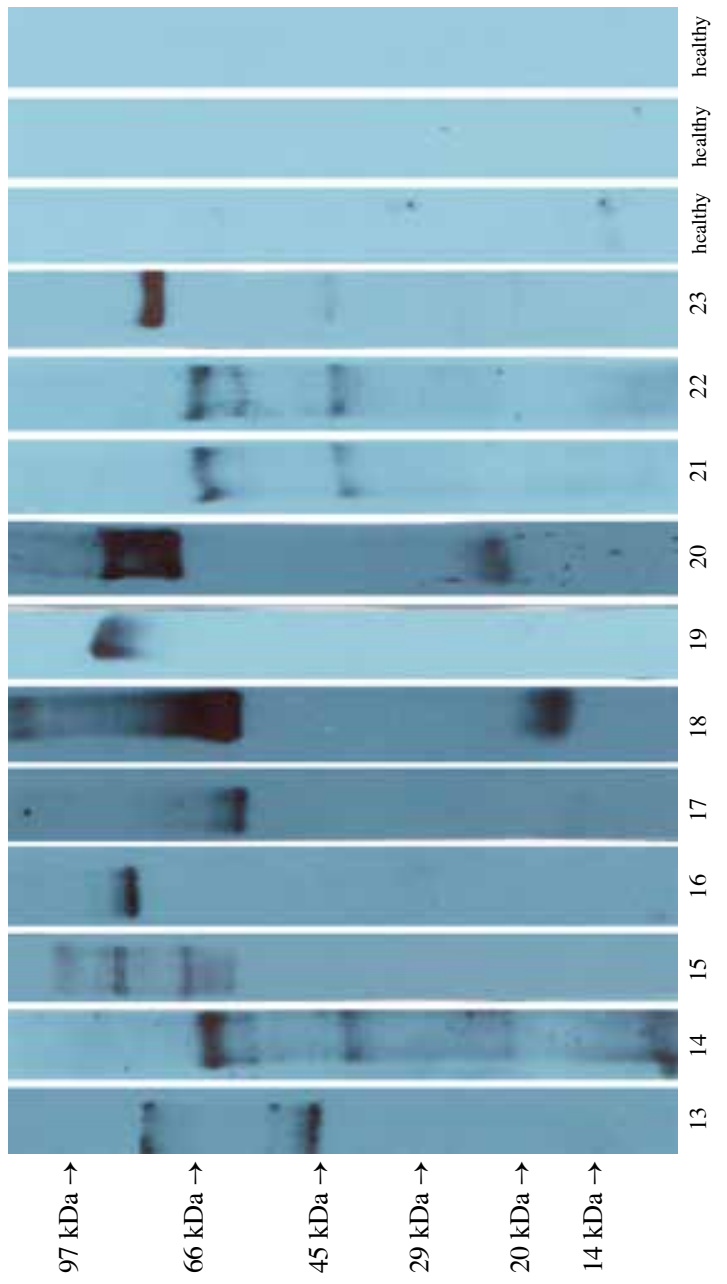

Fig. 2. Immunoblotting of pituitary microsomal proteins with sera from diabetes insipidus patients (13-23) and from control subjects (healthy)

tions were described by Manetti, where the occurrence of pituitary antibodies in $18 \%$ of patients with Hashimoto's thyroiditis and Graves' disease [27] was observed. Additionally, Garovic et al. described the presence of pituitary antibodies in patients with Wegener disease, while Kajiyama observed the presence of antibodies against vasopressin in systemic lupus erythematosus and dermatomyositis [28, 29]. According to previous studies, the incidence of antibodies directed against pituitary autoantigens of 65 and $67 \mathrm{kDa}$ weight suggested that the pituitary autoantigen might be glutamic acid decarboxylase (GAD). Two isoforms of glutamic acid decarboxylase, with weights of 65 and $67 \mathrm{kDa}$ (GAD65 and GAD67), are known so far. In fact, GAD65 is encoded by a gene located on chromosome 10 , and it is found mainly in the pancreatic cells. In contrast, GAD67 is encoded by a gene located on chromosome 2 and is found predominantly in the brain nerve cells, responsible for the synthesis of gamma-aminobutyric acid (GABA), 
Table 2. Assessment of pituitary hormones and thyroid antibodies in patients with diabetes insipidus

\begin{tabular}{|c|c|c|c|c|c|c|c|c|c|c|c|c|}
\hline No. & Patient & $\begin{array}{l}\text { Age } \\
\text { years }\end{array}$ & $\begin{array}{l}\text { Sex } \\
\text { F/M }\end{array}$ & $\begin{array}{c}\text { TSH } \\
{[\mathrm{mIU} / \mathrm{I}]}\end{array}$ & $\begin{array}{c}\text { LH } \\
{[\mathrm{mIU} / \mathrm{ml}]}\end{array}$ & $\begin{array}{c}\text { FSH } \\
{[\mathrm{mIU} / \mathrm{ml}]}\end{array}$ & $\begin{array}{c}\text { ACTH } \\
{[\mathrm{mIU} / \mathrm{ml}]}\end{array}$ & $\begin{array}{c}\text { HGH } \\
{[\mathrm{ng} / \mathrm{ml}]}\end{array}$ & $\begin{array}{c}\text { PRL } \\
{[\mu \mathrm{IU} / \mathrm{ml}]}\end{array}$ & $\begin{array}{l}\text { a-TPO } \\
{[\text { IUU/ml }]}\end{array}$ & $\begin{array}{c}\text { a-TG } \\
{[\mathrm{IU} / \mathrm{ml}]}\end{array}$ & $\begin{array}{c}\text { TRAb } \\
\text { [IU/ml] }\end{array}$ \\
\hline 1 & A.J. & 34 & $\mathrm{~F}$ & 0.2 & 0.1 & 0.1 & 0.2 & 0.1 & 89 & 256 & 89 & 0.7 \\
\hline 2 & R.K. & 37 & F & 0.1 & 0.0 & 0.2 & 0.3 & 0.1 & 132 & 786 & 12 & 0.3 \\
\hline 3 & P.G. & 40 & F & 0.0 & 0.2 & 0.3 & 0.2 & 0.0 & 54 & 43 & 123 & 1.2 \\
\hline 4 & J.K. & 44 & $\mathrm{~F}$ & 2.3 & 4.5 & 7.5 & 0.1 & 1.9 & 234 & 458 & 8 & 0.5 \\
\hline 5 & R.J. & 65 & $F$ & 0.2 & 0.1 & 0.1 & 0.0 & 0.3 & 43 & 23 & 342 & 0.9 \\
\hline 6 & A.O. & 39 & $\mathrm{M}$ & 0.3 & 0.2 & 0.1 & 0.5 & 0.0 & 76 & 345 & 21 & 1.1 \\
\hline 7 & R.O. & 59 & M & 0.1 & 0.0 & 0.2 & 0.1 & 0.1 & 35 & 34 & 91 & 0.6 \\
\hline 8 & M.R. & 59 & $\mathrm{~F}$ & 1.9 & 34 & 43 & 24 & 1.5 & 267 & 95 & 34 & 1.7 \\
\hline 9 & M.G. & 45 & F & 0.3 & 0.1 & 0.2 & 0.1 & 0.1 & 41 & 723 & 26 & 1.9 \\
\hline 10 & W.K. & 57 & F & 0.0 & 0.1 & 0.2 & 0.0 & 0.1 & 25 & 645 & 77 & 2.1 \\
\hline 11 & M.B. & 49 & $\mathrm{~F}$ & 2.2 & 12.6 & 17.9 & 41 & 1.1 & 324 & 54 & 14 & 0.2 \\
\hline 12 & A.K. & 55 & F & 0.1 & 0.2 & 0.1 & 0.0 & 0.1 & 76 & 567 & 7 & 0.6 \\
\hline 13 & M.G. & 50 & F & 1.5 & 10.4 & 16.5 & 39 & 2.1 & 214 & 112 & 167 & 0.4 \\
\hline 14 & M.W. & 52 & F & 0.1 & 0.0 & 0.1 & 0.0 & 0.2 & 23 & 12 & 6 & 0.6 \\
\hline 15 & B.L. & 54 & $\mathrm{~F}$ & 0.0 & 0.2 & 0.1 & 0.1 & 0.1 & 34 & 129 & 201 & 0.2 \\
\hline 16 & E.H. & 41 & M & 4.1 & 5.4 & 6.7 & 0.1 & 1.2 & 132 & 9 & 75 & 0.9 \\
\hline 17 & T.L. & 38 & $\mathrm{M}$ & 0.1 & 0.2 & 0.1 & 0.0 & 0.1 & 45 & 14 & 5 & 1.2 \\
\hline 18 & P.E. & 47 & $\mathrm{~F}$ & 0.0 & 0.2 & 0.1 & 0.2 & 0.1 & 51 & 89 & 41 & 0.5 \\
\hline 19 & J.F. & 62 & $\mathrm{~F}$ & 2.8 & 45 & 62 & 23 & 1.5 & 278 & 256 & 82 & 0.4 \\
\hline 20 & F.G. & 42 & $\mathrm{M}$ & 0.0 & 0.1 & 0.2 & 0.0 & 0.1 & 65 & 11 & 34 & 1.1 \\
\hline 21 & J.S. & 57 & M & 0.1 & 0.0 & 0.2 & 0.2 & 0.1 & 45 & 987 & 21 & 1.5 \\
\hline 22 & R.D. & 46 & $\mathrm{~F}$ & 0.0 & 0.1 & 0.1 & 0.2 & 0.0 & 21 & 34 & 92 & 0.4 \\
\hline 23 & U.W. & 41 & $\mathrm{M}$ & 3.9 & 4.3 & 5.2 & 0.0 & 1.1 & 141 & 287 & 15 & 0.2 \\
\hline 24 & M.W. & 42 & $\mathrm{~F}$ & 0.1 & 0.2 & 0.1 & 0.0 & 0.1 & 36 & 51 & 8 & 0.3 \\
\hline 25 & W.W. & 43 & M & 2.9 & 5.4 & 7.2 & 0.1 & 2.3 & 253 & 6 & 69 & 1.8 \\
\hline 26 & T.D. & 39 & $\mathrm{~F}$ & 0.1 & 0.0 & 0.2 & 0.0 & 0.1 & 38 & 523 & 10 & 1.6 \\
\hline 27 & H.N. & 44 & M & 0.0 & 0.1 & 0.2 & 0.1 & 0.0 & 28 & 8 & 134 & 0.4 \\
\hline 28 & K.P. & 45 & M & 2.3 & 5.6 & 6.5 & 34 & 2.1 & 245 & 455 & 7 & 2.8 \\
\hline 29 & A.P. & 36 & $\mathrm{~F}$ & 0.1 & 0.0 & 0.2 & 0.1 & 0.1 & 25 & 399 & 92 & 0.4 \\
\hline 30 & B.R. & 46 & $\mathrm{M}$ & 0.0 & 0.1 & 0.1 & 0.2 & 0.0 & 37 & 188 & 8 & 3.2 \\
\hline 31 & Z.M. & 42 & $\mathrm{M}$ & 0.1 & 0.2 & 0.1 & 0.0 & 0.1 & 87 & 10 & 87 & 0.5 \\
\hline 32 & D.S. & 33 & $\mathrm{~F}$ & 0.0 & 0.1 & 0.1 & 0.0 & 0.1 & 74 & 543 & 15 & 0.9 \\
\hline 33 & S.L. & 39 & M & 3.7 & 5.6 & 7.2 & 0.0 & 1.8 & 126 & 277 & 73 & 0.4 \\
\hline
\end{tabular}

Reference values: TSH (thyroid stimulating hormone) - 0.27-4.2 mIU/l, LH (luteinizing hormone) - 1.7-8.6 mIU/ml, FSH (follicle-stimulating hormone) - 1.5-12.4 $\mathrm{mIU} / \mathrm{ml}$, ACTH (adrenocorticotropic hormone) - 10-65 mIU/ml, HGH (human growth hormone) - 1.9-29 ng/ml, PRL (prolactin) - 85-390 $\mu \mathrm{IU} / \mathrm{ml}$, a-TPO (thyroid peroxidase autoantibody) - 0-60 IU/ml, a-TG (thyroglobulin autoantibodies) - 0-60 IU/ml, TRAb (TSH receptor antibodies) - 0-2 IU/ml

i.e. one of the major inhibitory transmitters [30]. Finally, Sawicka et al. [31-33] observed that the incidence of pituitary antibodies in autoimmune endocrine diseases was $41 \%$ and that these antibodies react mostly with an autoantigen weighing $68 \mathrm{kDa}$. Despite the number of studies conducted so far, only a few pituitary autoantigens responsible for the autoimmune processes have been identified. These include the growth hormone, neurospecific $\alpha$-enolase and the recently described PGSF1a (pituitary gland specific factor 1a) with a molecular weight of $16 \mathrm{kDa}$, as well as PGSF2 with a molecular weight of $27 \mathrm{kDa}$. Therefore isolation and characterization of other described pituitary autoantigens will al- 
low for a better understanding of the pituitary autoantibody formation process, and provide deeper insight into how they affect the pituitary gland hormonal function.

\section{The authors declare no conflict of interest.}

\section{References}

1. Komatsu M, Kondo T, Yamauchi K, et al. (1988): Antipituitary antibodies in patients with the primary empty sella syndrome. J Clin Endocrinol Metab 67: 633-638.

2. Kajita K, Yasuda K, Yamakita N, et al. (1991): Anti-pituitary antibodies in patients with hypopitiutarism and their families: longitudinal observation. Endocrinol Jpn 1991; 38: 121-129.

3. Kobayashi I, Inukai T, Takahashi M, et al. (1988): Anterior pituitary cell antibodies detected in Hashimoto's thyroiditis and Grave's disease. Endocrinol Jpn 35: 705-708.

4. Kosowicz J, Sawicka J, Gryczyńska M (1994): Pituitary antigens recognised by autoantibodies in endocrinopathies. Endokrynol Pol 45: 139.

5. Pouplard A, Bottazzo GF, Doniach D, et al. (1976): Binding of human immunoglobulins to pituitary ACTH cells. Nature; 261: 142-144.

6. Mirakian R, Cudworth AG, Bottazzo GF, et al. (1982): Autoimmunity to anterior pituitary cells and the pathogenesis of insulin dependent diabetes mellitus. Lancet 1: 755-759.

7. Sugiura M, Hashimoto A, Shizawa M, et al. (1986): Heterogenity of anterior pituitary cell antibodies detected in insulin-dependent diabetes mellitus and adrenocorticotropic hormone deficiency. Diabetes Res 3: 111-114.

8. Nishiyama S, Takano T, Hidaka Y, et al. (1993): A case of postpartum hypopituitarism associated with empty sella: possible relation to postpartum autoimmune hypophysis. Endocr J 40: 431-438.

9. Bottazzo GF, Doniach D (1978): Pituitary autoimmunity: a review. J Royal Society Med 71: 433-436.

10. Bottazzo GF, Florin-Christensen A, Pouplard A, et al. (1975): Autoantibodies to prolactin-secreting cells of human pituitary. Lancet 19: 97-101.

11. Yabe S, Murakami M, Maruyama K, et al. (1995): Western-blot analysis of rat pituitary antigens recognized by human antipituitary antibodies. Endocr J 42: 115-119.

12. Bando H, Iguchi G, Fukuoka H (2013): The prevalence of IgG4-related hypophysitis in 170 consecutive patients with hypopituitarism and/or central diabetes insipidus and review of the literature. Eur J Endocrinol 170: 161-172.

13. Nakasone Y, Oguchi K, Sato Y (2015): Rapid conversion of autoimmune hypophysitis to an empty sella with immediate lowering of the serum IgG4 level. Case Report. Neuro Endocrinol Lett 36: 112-114.

14. Scherbaum WA, Bottazzo GF (1983): Autoantibodies to vasopressin cells in idiopathic diabetes insipidus: evidence for an autoimmune variant. Lancet 1: 897-901.

15. Pivonello R, De Bellis A, Faggiano A (2003): Central diabetes insipidus and autoimmunity: relationship between the occurrence of antibodies to arginine vasopressin-secreting cells and clinical, immunological, and radiological features in a large cohort of patients with central diabetes insipidus of known and unknown etiology. J Clin Endocrinol Metab 88: 1629-1636.

16. Maghnie M, Ghirardello S, De Bellis A (2006): Idiopathic central diabetes insipidus in children and young adults is commonly associated with vasopressin-cell antibodies and markers of autoimmunity. Clin Endocrinol (Oxf) 65: 470-478.

17. De Bellis A, Sinisi AA, Pane E (2012): Involvement of hypothalamus autoimmunity in patients with autoimmune hypopituitarism: role of antibodies to hypothalamic cells. J Clin Endocrinol Metab 97: 3684-3690.

18. Chiloiro S, Tartaglione T, Angelini F (2017): An overview of diagnosis of primary autoimmune hypophysitis in a single prospective monocentric experience. Neuroendocrinology 104: 280-290

19. Falorni A, Minarelli V, Bartoloni E (2014): Diagnosis and classification of autoimmune hypophysitis. Autoimmun Rev 13: 412-416.

20. Ziemnicka K, Gut P, Gołąb M, et al. (2016): Pituitary microsomal autoantibodies in patients with childhood-onset combined pituitary hormone deficiency: an antigen identification attempt. Arch Immunol Ther Exp (Warsz) 64: 485-495.

21. Bensing S, Kasperlik-Załuska AA, Czarnocka B, et al. (2005): Autoantibodies against pituitary proteins in patients with adrenocorticotropin-deficiency. Eur J Clin Invest 35: 126-132.

22. Kasperlik-Załuska AA, Czarnocka B, Czech W (2003): Autoimmunity as the most frquent cause of idiopathic secondary adrenal insufficiency: report of 111 cases. Autoimmunity 36: 155-159.

23. Crock P, Salvi M, Miller A, et al. (1993): Detection of antipituitary autoantibodies by immunoblotting. J Immunol Methods 162: 31-40.

24. Crock PA (1998): Cytosolic autoantigens in lymphocytic hypophysitis. J Clin Endocrinol Metab 83: 609-618.

25. Nishiki M, Murakami Y, Ozawa Y, et al. (2001): Serum antibodies to human pituitary membrane antigens in patients with autoimmune lymphocytic hypophysitis and infundibuloneurohypophysitis. Clin Endocrinol 54: 327-333.

26. Lim S, Elston MS, Swarbrick MJ (2009): Lymphocytic hypophysitis with associated thyroiditis in a man with aseptic meningitis. Pituitary 12: 375-379.

27. Manetti L, Lupi I, Morselli LL (2007): Prevalence and functional significance of antipituitary antibodies in patients with autoimmune and non-autoimmune thyroid diseases. J Clin Endocrinol Metab 92: 2176-2181.

28. Garovic VD, Clarke BL, Chilson TS, Specks U (2001): Diabetes insipidus and anterior pituitary insufficiency as presenting features of Wegener's granulomatosis. Am J Kidney Dis 37: E5.

29. Kajiyama H, Terai C, De Bellis A (2004): Vasopressin cell antibodies and central diabetes insipidus in a patient with systemic lupus erythematosus and dermatomyositis. J Rheumatol 31: 1218-1221.

30. Baekkeskov S, Aanstoot HJ, Christgau S, et al. (1990): Identification of the $64 \mathrm{~K}$ autoantigen in insulin-dependent diabetes as the GABA-synthesizing enzyme glutamic acid decarboxylase. Nature 347: 151-156.

31. Sawicka J, Gryczyńska M, Baumann-Antczak A, Gut P (1999): Detection of pituitary autoantibody in patients with pituitary tumors and hypopituitarism. Pol Arch Med Wewn 101: 123-129.

32. Gut P, Kosowicz J, Ziemnicka K (2009): Isolation of pituitary autoantigen by affinity chromatography. Endokrynol Pol 60: 455-460.

33. Gut P, Fischbach J, Ziemnicka K (2014): Purification of pituitary autoantigen by column liquid chromatography and chromatofocusing. Cent Eur J Immunol 39: 46-50. 